\title{
Financial Technology in Financial Inclusions and its Implica- tions on Poverty from Indonesia
}

\author{
Fransiskus X Lara $\mathrm{Aba}^{1}$ and Denise Linardy ${ }^{2}$
}

\author{
Faculty Economics \& Business, Atma Jaya Catholic University of Indonesia, \\ Jakarta - Indonesia 12930 \\ *Correspondence: fransiskus.lara@atmajaya.ac.id
}

\begin{abstract}
The goal is to reduce poverty, the method used is a literature study to see the effect of using Financial Technology (Fintech) on financial inclusion, method to see the effect of financial inclusion on poverty. From the results of the tests, the use of Fintech can increase financial inclusion, thereby encouraging poverty alleviation. It can be seen that the Financial Inclusion variable has a significant and negative effect on the poverty variable. This shows that countries that have high levels of financial inclusion are generally estimated to have low poverty rates. Increasing a country's financial inclusion can reduce poverty.
\end{abstract}

Keywords: Economic well-being, Poverty alleviation, Quantitative data analysis

\section{Introduction}

In realizing the welfare of the people throughout the world, the United Nations (UN) formulates the Sustainable Development Goals (SDGs) that are expected to be achieved in 2030 that emphasize aspects of justice and equality. Of the 17 SDGs agreed upon; the objective of the first point is poverty alleviation. According to the United Nations (2015; ) and Better Than Cash Alliance (2016)., a country's economic growth must be inclusive and reach out to all communities to create sustainable and equitable employment. From this statement, it can be concluded that financial inclusion or financial inclusion is predicted to reduce a country's poverty level.

In the current era of Industry-based economy 4.0 and 5.0, financial services or financial technology-based financial services are emerging that provide convenience and comfort for users so that financial services are easier to use. With the facilities provided by Fintech, access to financial services can be accessed by more and more people in remote areas because it requires lower costs compared to conventional financial institutions (Dabla-Norris., Townsend, and Unsal; 2020; Ozili, 2018; Zetzsche., Buckley., Arner and Barberis; 2017). So that the use of Fintech is expected to increase financial inclusion and encourage poverty alleviation.

In this study, researchers will analyze the effect of using Fintech on financial inclusion and its impact on poverty. The method used is a literature study to see the effect of using Fintech on financial inclusion, and regression with the Ordinary Least Squares (OLS) method to see the effect of financial inclusion on poverty. The financial inclusion variable used is the number of accounts in financial institutions in a country taken from The Global Findex Database, while the poverty variable is the proportion of the total population of a country taken from The World Bank. 


\section{Literature Review}

Financial technology (Fintech) or financial technology are a combination of financial services and technology so that changing the business model from conventional to moderate can conduct long-distance transactions easily and quickly.

\subsection{Financial Technology}

The Financial Stability Board (FSB) classifies Fintech into four categories based on innovation, namely: (i) payment, settlement, and clearing, (ii) e-aggregator, (iii) risk management and investment, and (iv) peer-to-peer lending. Payment, settlement, and clearing are Fintech that provides payment system services, for example, OVO, Go-Pay, LinkAja. E-aggregator is a Fintech whose activities collect and process data that can be used by consumers to help make decisions, for example, by providing product comparisons, for example, Look and Tunaiku. Risk management and investment are Fintech that provide financial planning services and e-trading platforms as well as re-insurance, for example, Bareksa. Peer-to-peer lending brings lenders with loan seekers on the Fintech platform, for example, Modalku, Investee, Kredivo, and Amartha (Ozili, 2018; Abboushi., 2017; Kubrin., et all \& Ousey.,2011).

According to the Financial Services Authority (OJK), there are four risks to watch out for in Fintech, namely the risk of being attacked by hackers, the risk of default on Fintech intermediaries for financing or credit, the risk of fraud, and vulnerable abuse of client data (Altunbaş and Thornton. 2019; Kubrin., et all \& Ousey.,2011; Silalahi \& Aba; 2018).

\subsection{Financial Inclusion}

According to The World Bank (2018), financial inclusion is a situation where individuals and businesses have access to useful and affordable financial products and services to meet their needs such as transactions, payments, credit, and insurance. Access to transaction accounts is the first step in creating financial inclusion because with transaction accounts on people can save money and make and receive payments (Neaime and Gaysset: 2018; Bofondi and Gobbi; 2017; Borraz, \& Munyo; 2015).

Financial inclusion in its application can help in handling the rising levels of unemployment, poverty and inequality. The higher the level of public financial inclusion, the better they can make money management decisions and the use of financial products and services. In the end, increasing financial inclusion will sustain the development of the financial sector and encourage broader economic growth. According to the OJK Board of Commissioners, for every $20 \%$ increase in a country's financial inclusion rate, 1.7 million new jobs will be created. This shows the importance of increasing financial inclusio to reduce the level of poverty and inequality (M. E. Agwu., 2021; Asongu and Odhiambo, 2019; Aba., \& Irena; 2018; Bararuallo., \& Aba; 2017; Lara; \& Gde; 2018; Lara; 2018; Teja; 2017).

But according to Daryl C. \& Amolo N. (2018), increasing financial inclusion will not necessarily have a direct impact on poverty. Although access in financial services to the number of countries has increased rapidly in recent years, the evidence that this improves 
the quality of life for the poor is less visible (Huang and Zhang: 2019; Kim., Yu \& Hassan: 2018; Pew Research Center; 2016). Increasing the number of accounts in financial institutions can signify an increase in financial inclusion, but if the account is not used by the community, it will not have an impact on poverty (Koh., Lee, and Bomhoff: 2020; Gobble.,2018; Evans; 2017; Kubrin, \& Hipp; 2016).

\subsection{Poverty}

According to UNESCO (2001), poverty, also called poverty income is a situation where family income does not reach a set limit that is different in each country. Poverty can be classified into two types, namely absolute poverty and relative poverty. Absolute poverty includes poverty in terms of the amount of money needed to meet basic needs such as clothing, food, and shelter. Relative poverty includes poverty in terms of economic status where the community is declared poor if it cannot meet the standard of living in the country of residence.

According to The World Bank, the population with conditions of extreme poverty throughout the world in 2018 declined. However, the decline tends to slow down, causing concern related to the target of achieving poverty eradication in 2030. In order to deal with the slowdown, more investment is needed especially in building HR inclusive (Silalahi; et all; 2017; Aba., 2017; Aba., et all; 2015; Pare., \& Felson; 2014).

Based on the United Nations (2015), the Sustainable Development Goals (SDGs) expected to be achieved in 2030 are related to poverty alleviation as follows:

1. Eradicate extreme poverty throughout the world.

2. Reducing at least half of the proportion of the poor.

3. Implement a suitable social protection system nationally.

4. Increase the resilience of the poor and those who are in a vulnerable condition and reduce the impact of the economic, social and environmental crisis on them.

5. Ensure significant mobilization of resources from scattered sources.

6. Creating a policy framework that can be accepted at the national, regional and international levels that is pro-poor to increase investment in poverty alleviation activities.

\section{Research Methods}

In looking at the influence of the use of financial technology in financial inclusion and its influence on poverty levels, researchers used a literature study analysis and quantitative analysis by regression.

\section{Literature Analysis}

A literature study is a method of analysis conducted by looking for theoretical references and facts that are relevant to cases or problems found. In this study, a literature study was conducted to analyze the effects of financial technology on financial inclusion. 
Quantitative analysis is a method of analysis that is carried out using calculations based on the data used to reach a conclusion. In this study, a quantitative analysis was carried out by regression to see the effect of the level of financial inclusion on the level of poverty.

\section{Ordinary Least Squares (OLS)}

In this study, a quantitative analysis was conducted by regression with the Ordinary Least Squares (OLS) method on the variables used (Tchamyou., Erreyger and Cassimon: 2019; Pew Research Center: 2016; Messner., Raffalovich., \& Sutton; 2011).

The researcher used the POVERTY variable which represented the poverty level as the dependent variable and the FINANCIAL INCLUSION variable which represented the level of financial inclusion as an independent variable. So given the following equation 3.1:

$$
\operatorname{POVERTY}_{i}=\beta_{1}+\beta_{2} \text { FINANCIAL_INCLUSION }_{i}+u_{i}
$$

Based on the above equation, it is known that the poverty variable uses the Poverty Headcount Ratio indicator at National Poverty Lines (\% of the population) in each country. The FINANCIAL_INCLUSION i variable uses the Financial Institution Account indicator (\% Age 15+) in each country.

\section{Data Description}

The data used for the POVERTY variable uses the Poverty Headcount Ratio indicator at National Poverty Lines (\% of the population) from 50 countries, taken from The World Bank (2015). The FINANCIAL_INCLUSION variable data uses the Financial Institution Account indicator (\% Age 15+) from 145 countries, taken from the Global Findex Database (2014). The data used for the dependent variable uses data in 2015 while the data for independent variables use data in 2014 so that time lags to occur.

\section{Normality Test}

To ensure the OLS assumption is fulfilled, a normality test is performed using the Jarque-bear Test to see the normality of error distribution in equation (1), with the following hypothesis:

H0: Error with the normal distribution.

H1: Error is not normally distributed.

$\alpha=0.05$

JBstat X22

Reject HO if:

$\mathrm{p}$-value $(\mathrm{JB})<\alpha$

$2.77>0.05$

The results of the normality test can be seen in the attachment (1). Because the $\mathrm{p}$-value $(\mathrm{JB})>\alpha, \mathrm{H} 0$ is not rejected. At the $5 \%$ significance level, there is not enough evidence to prove that the error in equation (3.1) is abnormal. This proves that the error is normally distributed.

\section{Heteroscedasticity Test}


Heteroscedasticity test with the White Test was conducted to see whether the variability in equation (3.1) was constant and fulfilled the OLS assumptions, with the following hypothesis:

$\mathrm{H}_{0}: \operatorname{var}\left(u_{i}\right)=\sigma^{2}$ ( There is no heteroscedasticity in equation (1)

$\mathrm{H}_{1}: \operatorname{var}\left(u_{i}\right) \neq \sigma^{2}$ (There is heteroscedasticity in equation (1)

$\alpha=0.05$

$n R^{2} \sim X_{k-1}^{2}$

Reject $\mathrm{H}_{0}$ if :

$p$-value $<\alpha$

$0.1295>0.05$

The results of heteroscedasticity test can be seen in attachment (2). Because p-value> $\alpha, \mathrm{H} 0$ is not rejected. At the $5 \%$ significance level, there is not enough evidence to prove the existence of heteroscedasticity in equation (1), the error in the equation is constant.

\section{Results and Discussion}

\section{Effects of Financial Technology on Financial Inclusion}

Based on previous research by Peterson K. Ozili (2018), digital financial services through Fintech have a positive impact on financial inclusion in developing and developed countries, besides the comfort and convenience provided by Fintech to low-income and non-fixed income communities is more attractive than the costs greater value for the same service they get from conventional banking.

According to Accion (2016), it is known that Fintech has a positive influence on financial inclusion by helping small and medium enterprises and individuals who have not been reached by banks, and encouraging a decrease in the cost of inclusion programs to become more efficient and reach more consumers in remote areas. According to Irwan Trinugroho, UNS Management Lecturer, the presence of Fintech is considered to be able to increase financial inclusion in Indonesia. Communities previously unreachable by conventional financial institutions can be reached by financial service's thanks to Fintech. However, the presence of Fintech also poses a risk for the poor who cannot pay off the swelling debts of Fintech lenders or P2P lending. In addition, there is also the practice of "digging a hole to close a hole," that is, borrowers borrow money to pay other debts.

For this reason, it is recommended that Financial Services Authority (OJK) and educational institutions provide education to the public related to lending money through Fintech. For example, socializing the criteria for safe P2P lending, rules that must be known to the public before they owe, and teaching the community to adjust their ability to pay with the amount of money they want to borrow. According to Adrian A. Gunadi, Chair of the Indonesian Funding Fintech Association, one of the safest ways to obtain loans from P2P lending is to borrow from a Fintech company registered with the Financial Services Authority (Kling., 2020; Law., Kutan \& Naseem: 2018; Zhang: 2018; Kubrin., et all \& Ousey: 2011).

From these statements, it can be concluded that the use of Fintech has a positive influence on the level of financial inclusion of a country because Fintech provides convenience and comfort to the public in an inclusive manner at a lower cost than conventional 
financial institutions so that it can reach people in remote areas. However, in addition to these advantages, Fintech also creates a risk for people who cannot pay debts that continue to swell. For this reason, the government must educate the public about Fintech so that Fintech services can have a positive impact on financial inclusion and reduce existing risks.

\section{Effects of Financial Inclusion on Poverty Levels}

Based on the normality test and heteroscedasticity test that has been done, it is known that OLS assumptions have been fulfilled and can be regression in equation (1.) To see the effect of financial inclusion on poverty levels.

\section{Results of Regression}

The results of the regression carried out in equation (3.1) are shown in the following regression results table:

Table 3.1.Regression Results Table

\begin{tabular}{|ll|}
\hline $\mathbf{X}$ & $\mathbf{Y}=$ POVERTY \\
\hline $\mathrm{C}$ & \\
& $40.13^{* * *}$ \\
FINANCIAL_INCLUSION & $(3.53)$ \\
$\mathrm{N}$ & $-0.36^{* * *}$ \\
$\mathrm{R}^{2}$ & $(0.07)$ \\
\hline
\end{tabular}

The regression result's table processed in the Gretl application can be seen in the appendix. Based on the regression result's table, it can be seen that the FINANCIAL INCLUSION variable has a significant and negative effect of the POVERTY variable. This shows that countries that have high levels of financial inclusion are generally estimated to have low poverty rates. Increasing a country's financial inclusion can reduce poverty.

\section{Scatter plot}

To see the effect on the level of financial inclusion on poverty levels more clearly, data analysis was carried out by looking at scatter plots from POVERTY variable data and FINANCIAL_INCLUSION variables, as shown in the following graph: 


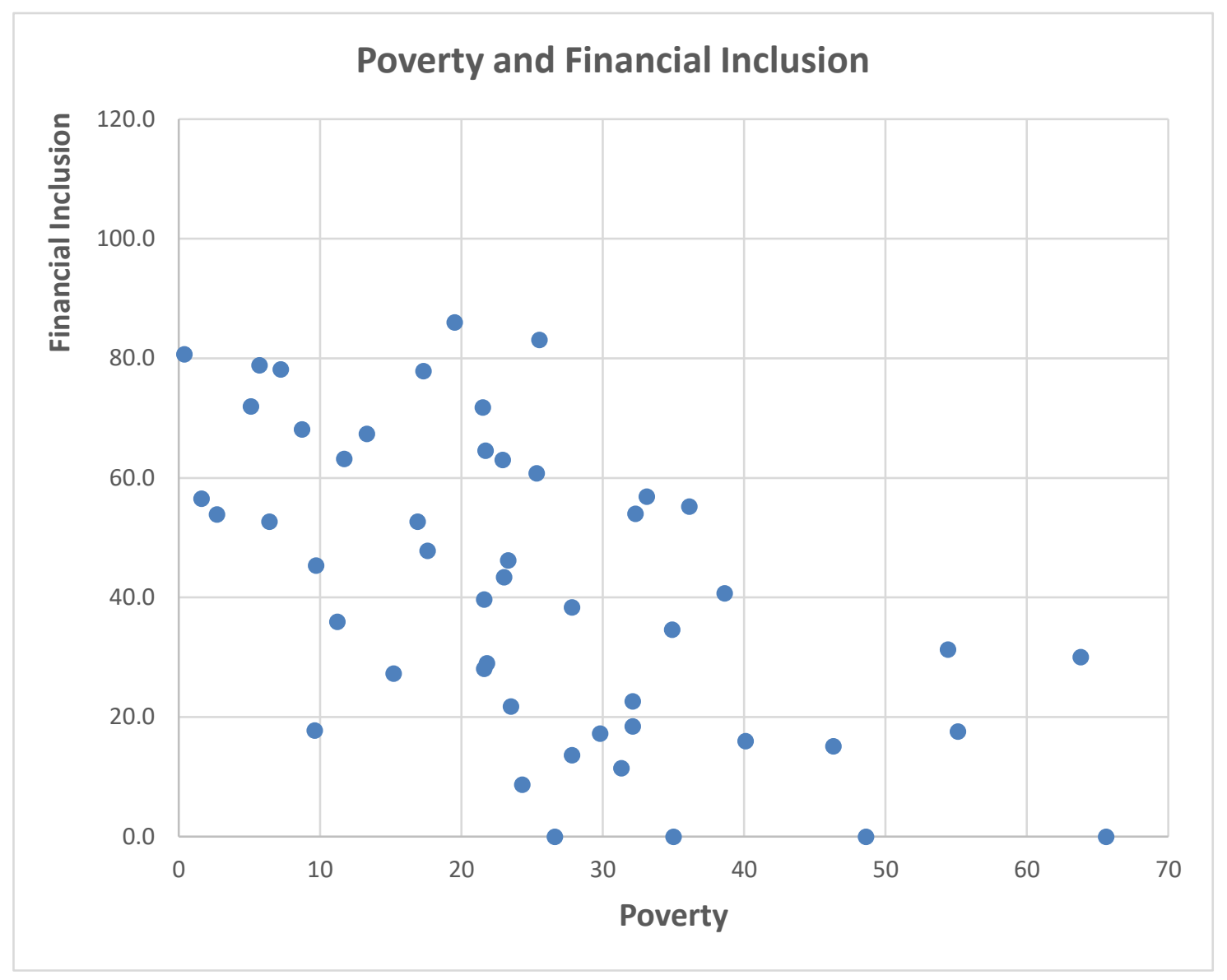

Based on the graph (3.1.), It can be seen that countries that have high levels of financial inclusion with high levels of financial inclusion tend to have low poverty rates. Conversely, countries that have high levels of poverty also tend to have low levels of financial inclusion. So that it can be concluded that increasing financial inclusion in general can reduce the poverty level of a country.

Based on the conclusions obtained from the research that has been done, researchers can provide some suggestions, namely as follows: (i). For the government, it is expected to be able to further support the development and licensing of Fintech companies in order to increase financial inclusion, which will reduce the country's poverty level by considering the security of each Fintech service and socializing its use to the public; (ii). For the general public, it is expected to be able to use Fintech services in daily transactions while considering the risks of these services.

\section{Conclusion}

Based on the analysis of the literature study, the use of Fintech was concluded to have a positive impact on the financial inclusion of a country because Fintech provides convenience and comfort to the public in an inclusive manner at a lower cost than conventional financial institutions so that it can reach people in remote areas.

However, in addition to these advantages, Fintech also creates a risk for people who cannot pay debts that continue to swell. For this reason, the government must educate the public about 
Fintech so that Fintech services can have a positive impact on financial inclusion and reduce existing risks.

Based on the results of the regression and scatter plots it is proven that the level of financial inclusion is estimated to have a significant and negative effect on the poverty level of a country. Countries that have high levels of financial inclusion are generally estimated to have low poverty rates. Increasing a country's financial inclusion in general can reduce poverty.

Author Contribution: The first author, FXLA, had primary responsibility for writing the draft and submitting the manuscript. Together with the second author, the first author conducted data analysis. Substantively revised draft of the article and maintain an overall critical view of the submitted manuscript. Second author. DL contributed to the analysis and with all drafts of submitted articles and manuscripts. All authors have read and approved the published version of the manuscript.

Funding: This research, which means we wrote this article, did not receive any external funding.

Acknowledgments: We would like to thank the participants in this study and the reviewers for useful advice.

Conflict of Interest: The authors declare no conflict of interest.

\section{Appendix:}

\section{Normality Test}

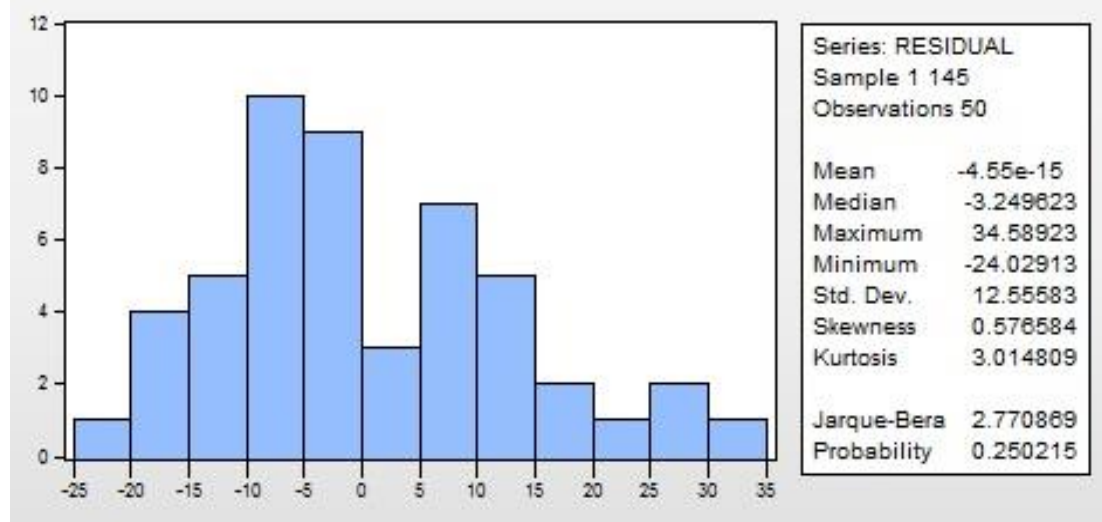

\section{Heteroscedasticity Test}

\begin{tabular}{|c|c|c|c|c|}
\hline $\begin{array}{l}\text { F-statistic } \\
\text { Obs*R-squared } \\
\text { Scaled explained Ss }\end{array}$ & $\begin{array}{l}2.375316 \\
2.357619 \\
2.188870\end{array}$ & \multicolumn{2}{|c|}{$\begin{array}{l}\text { Prob. } F(1,48) \\
\text { Prob. Chi-Square(1) } \\
\text { Prob. Chi-Square(1) }\end{array}$} & $\begin{array}{l}0.1298 \\
0.1247 \\
0.1390\end{array}$ \\
\hline \multicolumn{5}{|l|}{$\begin{array}{l}\text { Test Equation: } \\
\text { Dependent Variable: RESIDng } \\
\text { Method: Least Squares } \\
\text { Date: o3/20/19 Time: } 12: 14 \\
\text { Sample: } 6144 \text {. } \\
\text { Included observations: } 50\end{array}$} \\
\hline Variable & Coefficient & Std. Error & t-Statistic & Prob. \\
\hline FINANCIAL_INCLUSIONn'2 & $\begin{array}{r}206.9443 \\
-0.022162\end{array}$ & $\begin{array}{l}45.96478 \\
0.014380\end{array}$ & $\begin{array}{r}4.502237 \\
-1.541206\end{array}$ & $\begin{array}{l}0.0000 \\
0.1298\end{array}$ \\
\hline $\begin{array}{l}\text { R-squared } \\
\text { Adjusted R-squared } \\
\text { S.E. of regression } \\
\text { Sum squared resid } \\
\text { Log likelihood } \\
\text { F-statistic } \\
\text { Prob(F-statistic) }\end{array}$ & $\begin{array}{l}0.047152 \\
0.027301 \\
218.4790 \\
2291187 \\
-339.2609 \\
2.375316 \\
0.129834\end{array}$ & \multicolumn{2}{|c|}{$\begin{array}{l}\text { Mean dependent var } \\
\text { S.D. dependent var } \\
\text { Akaike info criterion } \\
\text { Schwarz criterion } \\
\text { Hannan-Quinn criter. } \\
\text { Durbin-watson stat }\end{array}$} & $\begin{array}{l}154.4958 \\
221.5239 \\
13.65043 \\
13.72692 \\
13.67956 \\
1.235790\end{array}$ \\
\hline
\end{tabular}


3. Regression Results Table

\begin{tabular}{|c|c|c|c|c|}
\hline Variable & Coefficient & Std. Error & t-Statistic & Prob. \\
\hline FINANCIAL INCLUSION & $\begin{array}{r}40.01355 \\
-0.359569\end{array}$ & $\begin{array}{l}3.533396 \\
0.072633\end{array}$ & $\begin{array}{r}11.32439 \\
-4.950497\end{array}$ & $\begin{array}{l}\text { 0.0000 } \\
\text { o.0000 }\end{array}$ \\
\hline $\begin{array}{l}\text { R-squared } \\
\text { Adjusted R-squared } \\
\text { S.E of regression } \\
\text { Sum squared resid } \\
\text { Log likelihood } \\
\text { F-statistic } \\
\text { Prob(F-statistic) }\end{array}$ & $\begin{array}{r}0.337999 \\
0.324207 \\
12.68594 \\
7724.788 \\
-196.9511 \\
24.50742 \\
0.000010\end{array}$ & \multicolumn{2}{|c|}{$\begin{array}{l}\text { Mean dependent var } \\
\text { S.D. dependent var } \\
\text { Akaike info criterion } \\
\text { Schwarz criterion } \\
\text { Hannan-Quinn criter. } \\
\text { Durbin-Watson stat }\end{array}$} & $\begin{array}{l}24.94400 \\
15.43177 \\
7.958044 \\
8.034525 \\
7.987168 \\
1.331711\end{array}$ \\
\hline
\end{tabular}

\section{References}

Aba, F. X., Yussof, O. M., \& Mohd, S. B. (2015). Analysis of economic structure in poverty eradication in the province of East Nusa Tenggara Indonesia. Procedia-Social and Behavioral Sciences, 211, 81-88.

Aba, F. (2017). Effect of Income, Population, Government Spending, Export Goods and Services of Regional Economic Sector in Indonesia. In 19th International Scientific Conference on Economic and Social Development Melbourne, Australia (pp. 9-10).

Aba, F. X. L., \& Irena, F. (2018). Stock Investment Decisions to Refund Level of Profits In Dealing Probability of Financial Market Risk. Global Journal of Economics and Business-Vol, 5(2), 242.

Abboushi, S. (2017). “Global Virtual Currency. Brief Overview.” The Journal of Applied Business and Economics 19(6): 10-18. [ Accion.org. (2018). Digital Lenders Can Help Unlock Full Financial Inclusion.

Altunbaş, Y., and J. Thornton. (2019). “The Impact of Financial Development on Income Inequality: A Quantile Regression Approach." Economics Letters 175: 51-56.

Asongu, S.A., and N. M. Odhiambo. (2019). “How Enhancing Information and Communication Technology Has Affected Inequality in Africa for Sustainable Development:An Empirical Investigation. " Sustainable Development 1: 1-10.

Bank Indonesia. (2016). "Financial Technology" .

Bararuallo, F., \& Lara Aba, F. X. (2017). Influence Factors Determinants Absolute Poverty; Case Study in Indonesia. Global Journal of Business and Social Science Review (GJBSSR), 5(3), 69-75.

Better Than Cash Alliance. (2016). How to define digital payments. Retrieved May 31, 2016,

Bofondi, M., and Gobbi, G. (2017). The big promise of fintech. European Economy 2:107-119.

Borraz, F.,\& Munyo, I. (2015). Conditional cash transfers and crime: Higher income but also better loot (Working Paper). Centro de Economía, Sociedad y Empresa del IEEM, Universidad de Montevideo. 
Collins, Daryl \& Amolo Ng'weno. (2018). Do Financial Inclusion Efforts Really Have an Impact on Poverty?. Stanford Social Innovation Review.

Dabla-Norris, E., Y. Ji, R.M. Townsend, and D. F. Unsal. (2020). “Distinguishing Constraints on Financial Inclusion and Their Impact on GDP, TFP, and the Distribution of Income." Journal of Monetary Economics.

Evans, G. L. (2017). “Disruptive Technology and the Board: The Tip of the Iceberg 1.” Economics and Business Review 3(17): $205-223$.

Global Findex Database. (2014). Financial Institution Account (\% age 15+).

Gobble, M. M. (2018). Digitalization, digitization, and innovation. Resources. Research-Technology Management 61(4): 56-59.

Huang, Y., and Y. Zhang. (2019). "Financial Inclusion and Urban-Rural Income Inequality: Long-Run and Short-Run Relationships." Emerging Markets Finance and Trade 56 (2): 457-471.

Kubrin, C. E., \& Hipp, J. R. (2016). Do fringe banks create fringe neighborhoods? Examining the spatial relationship between fringe banking and neighborhood crime rates. Justice Quarterly, 33, 755-784.

Kubrin, C. E., Squires, G. D., Graves, S. M., \& Ousey, G. C. (2011). Does fringe banking exacerbate neighborhood crime rates ? Criminology \& Public Policy, 10, 437-466.

Lara, A. F. X., \& Gde, L. N. L. (2018). Study of local government problems in implementation of development budget policy planning in economic sector of Indonesia. Russian Journal of Agricultural and Socio-Economic Sciences, 75(3).

Lara, A. F. X. (2018). Acceleration of economic policy and implementation strategy for development planning in poor area. Russian Journal of Agricultural and Socio-Economic Sciences, 76(4).

Law, S. H., Kutan, A. M., \& Naseem, N. A. M. (2018). The role of institutions in finance curse: Evidence from international data. Journal of Comparative Economics, 46(1), 174-191.

Kim, D.-W., Yu, J.-S.,\& Hassan, M.K. (2018). Financial inclusion and economic growth in OIC countries. Research in International Business and Online, 43, 1-14.

Kling, G. (2020). “Measuring Financial Exclusion of Firms.” Finance Research Letters.

Koh, S. G., G. H. Lee, and E. J. Bomhoff. (2020). “The Income Inequality, Financial Depth and Economic Growth Nexus in China.” The World Economy 43 (2): 412-427.

Messner, S. F., Raffalovich, L. E., \& Sutton, G. M. (2011). Poverty, infant mortality, and homicide rates in cross-national perspective: Assessments of criterion and construction validity. Criminology, 48, 509-537.

M. E. Agwu (2021) Can technology bridge the gap between rural development and financial inclusions?, Technology Analysis \& Strategic Management, 33:2, 123-133 
Neaime, S., and I. Gaysset. (2018). “Financial Inclusion and Stability in MENA: Evidence from Poverty and Inequality." Finance Research Letters 24: 230-237.

Ozili, Peterson K. (2018). Impact of Digital Finance on Financial Inclusion and Stability. Borsa Istanbul Review.

Pare, P.-P., \& Felson, R. (2014). Income inequality, poverty and crime across nations. The British Journal of Sociology, 65, 434-458.

Park, C.-Y.,\& Mercado, R.V. Jr. (2018). Financial inclusion, poverty, and income inequality. The Singapore Economic Review, 63(01), 185-206.

Pew Research Center. (2016). Online shopping and e-commerce. Retrieved from http://www.pewinternet.org/2016/12/19/onlineshopping-and-e-commerce/

Tchamyou, V.S., G. Erreyger,and D. Cassimon. (2019). “Inequality, ICT and Financial Access in Africa.” Technological Forecasting and Social Change 139: 169-184.

Silalahi, E. E., \& Aba, F. X. L. (2018). Financial Planning on Economic Development and Implementation of Budget Use at Political Decision in Indonesia. Financial Planning, 9(8).

Silalahi, E. E., Aba, F., Sugiharto, S., \& Lydia, N. L. G. (2017). Finance of Regional Government: An Evaluation of Economic Development Policy Budget. In 6th Global Conference on Business and Social Sciences, December 4th to 5th.

Teja, A. (2017). “Indonesian Fintech Business: New Innovations or Foster and Collaborate in Business Ecosystems?” The Asian Journal of Technology Management 10(1): 10-18.

The World Bank. (2018). Financial Inclusion: Overview.

The World Bank. (2015). Poverty Headcount Ratio at National Poverty Lines (\% of population).

United Nations. (2015). Sustainable Development Goals: Poverty.

UNESCO. (2001). Social and Human Sciences: Poverty.

Zetzsche, D. A., Buckley, R. P., Arner, D. W., and Barberis, J. N. (2017). Regulating a revolution: From regulatory sandboxes to smart regulation. Fordham Journal of Corporate and Financial Law 23: 31.

Zhang, X., J. Zhang, and Z. He. (2018). “Is FinTech Inclusive? Evidence from China's Household Survey Data.” Paper presented at the 35th IARIW General Conference, Copenhagen, 20-25 August. 